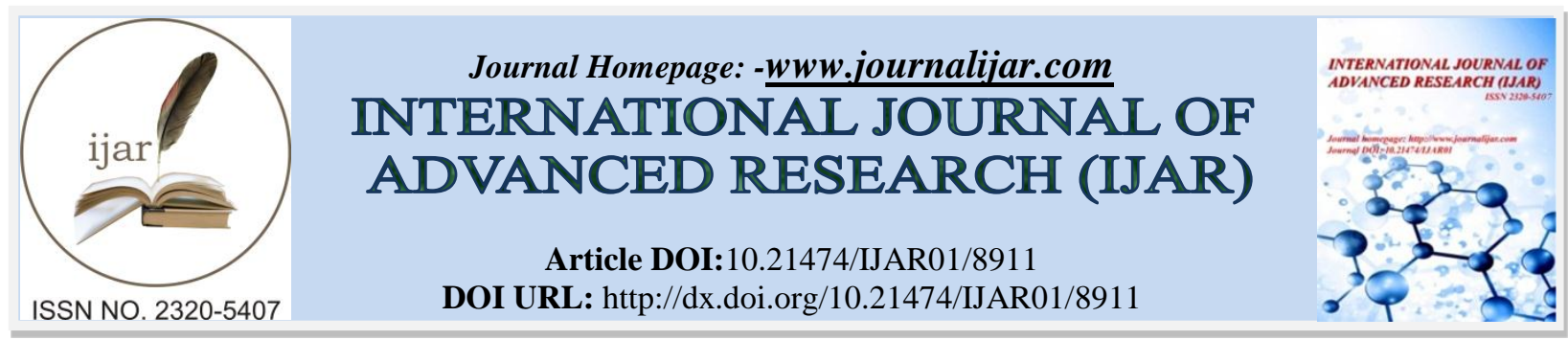

RESEARCH ARTICLE

\title{
HOW FARMERS EXPERIENCE CHANGE IN TRANSITION: THE CASE OF RICE FARMERS SHIFTING TO AQUACULTURE IN BANGLADESH.
}

\author{
M. Nahid Sattar. \\ Assistant Professor, Department of Agricultural Economics, Bangladesh Agricultural University, Mymensingh, \\ Bangladesh.
}

\section{Manuscript Info}

Manuscript History

Received: 12 February 2019

Final Accepted: 14 March 2019

Published: April 2019

Key words:-

Fish farming, agricultural change, land use change, motivation for farming.

\section{Abstract}

Freshwater aquaculture has expanded rapidly in Bangladesh over the last few decades, sometimes by converting rice fields into fish ponds. This research used qualitative cases studies to understand the experiences of two farmers who have shifted from rice production to fish farming. At first, the study described the experience of a farmer who had started fish farming in 1981 as an experiment with something he loves, but gradually became involved with it professionally as it was profitable. As a pioneer commercial fish farmer in his area, he faced many obstacles during the early days of his business, but he persisted in this profession and became successful. Next, the study described the experience of a farmer who was induced into fish farming in 2000 when he witnessed others prospering in doing it, while he was struggling with the growing challenges in rice production. This farmer learned fish farming from family and friends, and excelled in this profession. This qualitative research supported the claim from other studies that earning higher profit was a motive for the farmers' making the shift; but then added on with the understanding of how their life experiences lead a farmer to adopt a more profitable practice.

Copy Right, IJAR, 2019,. All rights reserved.

\section{Introduction:-}

Historically, the rural landscape in Bangladesh consists of miles and miles of green or golden crop fields, trees, rivers and rural houses; albeit majority of the fields are of one type: rice fields. However, over the last 20 years or so, something has changed in some parts of the country. Miles and miles of green fields have been replaced by fish ponds. Although fish cultivation has been practiced in Bangladesh for centuries, the massive expansion of fish ponds in some parts of the country, like in the district of Mymensingh, is only a recent phenomenon. Behind this change in landscape, there is a bigger story of the people who are making this change: the rice farmers who are making the shift. This research uses multiple qualitative cases studies to understand the experiences of those farmers.

Fishing is a very important activity in Bangladesh not just because of its contribution to diet and the economy, but also for its strong cultural attachment to the people (Belton et al., 2011; Ghose, 2014). The fisheries sector contributed 25\% to agricultural GDP in 2012 and provides about two-thirds of animal protein (BBS, 2014). These figures include both captured (inland and marine) and cultured fish. Historically, captured fish occupied a larger share; however, because of over fishing from inland natural sources and other reasons, supply of captured fish has

Corresponding Author:-M. Nahid Sattar.

Address:-Assistant Professor, Department of Agricultural Economics, Bangladesh Agricultural University, Mymensingh, Bangladesh. 
been declining over the years. Therefore, there have been efforts to increase fish production over the last few decades, particularly efforts that emphasize the practice of aquaculture (Belton et al., 2012). Aquaculture is the farming of aquatic organisms, including fish, mollusks, crustaceans and aquatic plants (FAO, 1988), which is predominantly based on (inland) freshwater. The geographical conditions in Bangladesh are considered to be some of the most suitable in the world for freshwater aquaculture (Ahmed \& Toufique, 2015). Many government and nongovernment efforts have even tried to popularize aquaculture and fish cultivation in rice plots. While the later effort has not been successful so far, freshwater pond aquaculture has seen significant expansion in some areas of the country through conversion of rice fields and wetlands to ponds (Belton, 2011; Hernandez et al, 2017; Kamala, 2016). The issue of agricultural households converting rice land to fish pond can be seen from the view point of change in land use by the agricultural household, and this will be the focus of this research.

Now, let us look at the situation of the rice farmer in the economy of Bangladesh, the largest group of farmers in the country. The economy of the country is going through transformations over the last few decades; with average incomes rising and all the sectors (agriculture, manufacturing and industry) experiencing positive growth rates (BBS, 2016). Rice farmers, like any other groups within the population, are facing the effects of this transition and, in certain areas of the country; some of them are shifting to aquaculture. Economic theory suggests that rice farmers - like any other economic agents - would change land use if it is more profitable for them. However, they may not be able to do so because of reasons such as resource constraints, higher risk, lack of technology or knowledge, legal restrictions, etc., even if there is economic incentive to do so. The financial incentive may have been there, as fish is more profitable than rice per acre of land (Gurung et al., 2016; Rahman, 2014), but the constraints may prevent a farmer from making a shift. But over the last few decades, the financial constraint may have been eased by capital accumulation by success in rice production through use of green revolution technologies, earnings from non-farm income and/or migration (Hernandez et al., 2017). Labor shortage during peak demand periods and increase in labor wages are some of the problems rice farmers are facing in Bangladesh. As fish cultivation is less labor intensive than rice production, this is a motivation for some farmers to shift to fish cultivation (Gurung et al., 2016). Also, income from fish culture is available year round (Rahman, 2014), as opposed to rice production (which is seasonal), and this can be another motivation for agricultural households to shift from rice production to aquaculture.

The research conducted on this phenomenon so far has been based primarily on the positivist paradigm, where the quantitative studies have mostly focused on predicting farmers' behaviors based on the profitability of fish production to the farmer. This paper shifts the focus of inquiry to understanding the phenomenon of change experienced by the farmers and explains why a qualitative inquiry under the interpretivist paradigm can enhance understanding of this important phenomenon. The quantitative studies reviewed here sometimes give only descriptive statistics of transformation rates and related variables, failing to provide any insights or rich descriptions on why and how such changes are taking place (Doss, 2003). These studies mostly view farmers as passive agents in their land use decisions, with factors happening beyond their control simply guiding them to take the actions they have taken. For example, the point about availability of knowledge about aquaculture adoption demonstrates that increased knowledge of aquaculture was available to certain farmers, and show that a higher percentage among them adopted aquaculture, compared to another group which had less knowledge about aquaculture. However, such reasoning does not shed any light on why or how the knowledge of the farmer led to the adoption of such a practice - possibly because it was not a goal of the positivist approach to do so. Understanding farmers' reasons and processes experienced is important because the farmers may have had knowledge about some other alternative agricultural or business opportunity as well, but chose to do aquaculture. One relevant example is a study on land use strategies by agricultural households in Vietnam, which found people leaving agricultural production and moving to non-farm sectors during economic growth (Nguyen, 2011, cited in Nguyen et al., 2014).

The shift towards aquaculture could also have been motivated by other changes in the economy which are not directly linked to the farmers themselves, but they experience the impact of those changes. For example, increase in demand for fish as average incomes grow, and the development of other sections of the fish value chain, such as supply of fish feed, hatcheries, and transportation. A study on global land use change mentioned urbanization as an important factor of land cover change, not only by building infrastructure, but also through transforming rural-urban linkages and changing rural demographics (Lambin et al., 2001). Another study argued that in addition to commonly discussed factors related to changes in agricultural production - like population growth - other less discussed causes including changes in lifestyle and food preferences are also important drivers of land use change (Heilig, 1994). Similarly, demand pull from international markets can also drive land conversion (Flaherty, 1999). 
A research in Kenya found increased knowledge of aquaculture and favorable social perception towards this practice had positive influence on farmers adopting it (Njue \& Macharia, 2015). Another study made an interesting observation that economic growth in an unorganized developing economy led to capital accumulation in the hands of certain sections of the population, but there was not enough scope for investing in industrial sectors (Thuo, 2013). This phenomenon can also be relevant for freshwater aquaculture expansion in Bangladesh, as the country's economy is growing, and there are some people in the villages that are getting richer. However, they may not have the capability to invest in more productive avenues beyond the village, and thus restricting themselves to whatever best is available to them nearby, which could be aquaculture in some cases.

So, this paper argues that the phenomenon through which a farmer chooses to shift a part or entire amount of his or her land to aquaculture from rice production cannot be adequately described as a linear change. Rather, it is a change in a particular direction that may have been led by his or her characteristics and experiences, and embedded in the social, economic, cultural and political contexts he or she is experiencing in life. Hence a rich and credible description of the context and phenomenon under study can provide important insights into the story, and a qualitative inquiry can put the 'human' experiences of the farmer at the heart of the change occurring, which a quantitative research may be unable to do. Stake (1978) highlighted this problem by quoting Dilthey (1910), who argued that more objective and "scientific" studies did not do the best job of acquainting man with himself. The aim for this inquiry is to be a study of human experiences.

\section{Research Question}

Based on the above background, this study is about exploring the experiences of the farmers making that change, and understanding how they have shifted to aquaculture. The specific research question is:

How have farmers experienced the changing process from rice cultivation to fish farming in Bangladesh?

\section{Conceptual Framework}

The quantitative studies on the adoption of aquaculture present a static view of why farmers are using their land as they are, and the dynamics of their decision is not captured in their analysis. The goal of this research is to understand the phenomenon of change experienced by farmers in the transition process, not predict their behavior. Multiple case study method was used for this research. The case study method is appropriate to answer the why and how this shift is taking place (Yin, 1994; cited in Baxter \& Jack, 2008). Since the aim of this study is 'understanding' and 'extension of experience', the multiple case study method can be a good approach for this research (Stake, 1978). It will help the researcher to recognize the complexity of the situation (Stake, 1995; cited in Hellstrom, et al., 2005), and allow the phenomenon of farmers making land use choices under the context of economic transition to be well explored and understood (Baxter and Jack, 2008). Also, this method allows us to compare the experiences of rice farmers from two different time periods or settings who shifted to aquaculture.

Economic theory may attribute this change to the profit motives of the farmers, which is, as they found fish production to be more profitable than rice, the farmers who were capable, shifted to aquaculture. So, it is expected to see profitability as a part of the farmers' story to make this shift. But it may not be the whole story. For example, arguing that profitability motivated a farmer does not explain how that played a role in his life experiences to make him make this decision. The profit motive is not sufficient to explain why a majority of farmers are still cultivating rice in Bangladesh. The farmer is an individual with particular characteristics and unique life experiences, and the events or experiences in his/her life influence him/her to make certain decisions about land use. This research aims to explore his experiences to understand how some of them have made the shift.

\section{Methods:-}

This study involved land- owning farmers who had been cultivating rice, but then shifted to aquaculture. It did not include farmers who have been fish farmers all along in their lives, or shifted from other professions. The unit of analysis in this study is the land owning rice farmer, who has shifted to aquaculture. Two farmers were chosen purposively from Mymensingh district of Bangladesh (the highest freshwater aquaculture area) with help from local experts. The real names of the farmers have been concealed, and replaced with S1 and S1 in the discussion.

The interview protocol was prepared based on the objectives of the study. The interviews were done in the Bangla language, the first language for both myself and the farmers. During the interview, at first, the respondents were informed about the purpose of the study. I explained my positionality and secured their consent to conduct and 
record the interview. I attempted to build rapport with the interviewees and listen to them empathically. After the interviews, I analyzed the data from the recorded conversation and wrote this report.

\section{Results And Discussion:- \\ The Experiences of the Farmers}

The first case was of Mr. S1 from village Badedhonpa under Mymensingh district of Bangladesh. He has been an aquaculture farmer since 1981. Back then he was involved in a number of professions, including rice farming and timber processing. Those professions were profitable, but still he transformed his occupation and converted his land over time, and now his main source of income is aquaculture. Even before he started fish cultivation, he had a passion for fishing from rivers or other water bodies. In his words, "I liked fishing, just as some people like sports". But fishing occasionally as a recreational activity is different from cultivation for a living. Toward the end of our conversation, S1 revealed how he got interested in that.

Mr. S1 first started fish farming in his low lying rice field, when he constructed barriers around the field to make the water stand and casually released some fish fingerlings in that area. This practice is seen in some places in Bangladesh, where fish is cultivated in the standing water of low-lying rice fields. But this method has its problems, and has not been very popular with most farmers. Although S1's motive was not particularly to make a big profit out of the fish, his first harvest was profitable. Yet, what tempted him to continue was not profit alone, but the prospect of an independent 'clean' business, where he did not need to engage in any unfair practices to earn a profit. Therefore, he went on to gradually convert his rice fields into fish ponds, and diverted attention from his other professions into aquaculture.

Back in the early 1980s, it was not the easiest profession to go into. No one else in his Union - which is a collection of a number of villages - was into fish production, and people in general would not regard fish farming as a 'prestigious' profession. Moreover, coming from an influential family in the village - his father was the Chairman of the local Union Council - fish farming was one of the least likely activities one could expect someone like him would do. There were not many input sellers or intermediary buyers of fish in nearby areas back then. The risk of investing in this new area was big. He never received any assistance from any government agency while making this shift. However, the love of fishing and the profit he made from his first endeavor ensured that there was no looking back.

When he looks back, S1 - the pioneer of aquaculture in his area - is happy that he made the shift back in 1981. He also reflected on the phenomenon of conversion from rice to fish farming under current situation. According to him, labor cost is rising rapidly in rural Bangladesh; hence a lot of rice farmers have the incentive to make the shift, as the next case illustrates. He thinks that the attack of fish diseases is a major problem for fish farmers, and if better ways could be found to address this issue, aquaculture would further flourish in his area.

The other farmer I interviewed was Mr. S2, from the village Dhonpatikri under Mymensingh district of Bangladesh. Unlike Mr. S1, S2 is a recent fish farmer, who started aquaculture in 2000. Before that his main professions were rice production and dairy farming. As labor wages were rising and hired labor supply shrunk in his area, it became increasingly difficult to make a profit out of rice production, which is very labor intensive. He observed in 1998 that his uncles who were living in a neighboring village were cultivating fish and made a big profit, while he was struggling with rice production. He would regularly visit their place and see their aquaculture activities. Ultimately he became encouraged to think about starting his own fish farming. His uncles also encouraged him to do so, and provided him necessary advice as a beginner. So he started in 2000 by converting one fifth of his rice field to a fish pond. As he made profit from that, he continued in this occupation. Higher profit seems to be the main motivating factor and his own uncles doing it was the main encouragement for Mr. S2 in making the shift. No one else was cultivating fish in his village back then. But now, just like S1's village, things have changed as many people have started aquaculture, and many others are interested in doing it.

Mr. S2 also did not receive any formal training, and has not been in contact with any government aquaculture extension agents. He learnt all the 'tricks of the trade' from his uncles. The situation he faced at the beginning of his fish farming career was somewhat different from the situation S1 had faced. By 2000, there were already a number of fish farmers in adjacent areas, if not in his village. This means that better marketing channels existed for the inputs he needed as a number of professional fish feed and fingerling sellers were already there when he started. Therefore we can say that there was more market support for his activity, compared to the case of Mr. S1. 
Mr. S2 is very happy to have made the shift, as he says that he would never have made the type of profit (or income) with rice that he is making now through fish. According to S2, "Aquaculture is so profitable, that only if the fish do not die from diseases, then even if the price is low, we get good profit". Thus adoption of aquaculture has not only changed his economic status, but many people doing it in his area also changed the overall socioeconomic condition of his village. As he explained, "The village has become a town after the growth of aquaculture".

\section{Comparison between the Cases}

The stories of Mr. S1 and Mr. S2 have both similarities and dissimilarities. Mr. S1 started fish farming more as an experiment with something he loves. It seemed that making profit out of it was not his priority when he first did it. But later on, as he realized that it was profitable, and that it was a type of business that he liked, he gradually became involved with it professionally. On the other hand, Mr. S2 did not have any particular 'love' for fishing, but was rather induced into the profession as he witnessed his relatives prospering in doing it, while he was struggling with the growing challenges in rice production. In other words, the 'profit motive' played a key role in S2's initiation, but not in S1's case, although it contributed to his continuing in this profession.

One similarity in their stories is how they managed the risk associated with any new investment. Both of them seemed to be risk-takers, as they were willing to try something new for different reasons, which many farmers in developing countries do not like doing. But they were not gambling with their money either, as none of them invested big proportions of their resources into fish farming straight away, rather starting with conservative amounts, and gradually building upon it. So it seems that both of them acknowledged the risk in their investment, but that did not deter their participation, and they found ways to manage the risk efficiently. Another similarity is that neither of them received any government assistance or training, but still managed to prosper in their endeavor.

One key difference between the two cases is in the initial conditions they experienced. Mr. S1 started about 20 years earlier than Mr. S2, when fish farming was not even seen as a 'respectable' profession in his village. The input and output linkages were not well established back then. On the other hand, when Mr. S2 came into this business in 2000, the people's perceptions had changed, and there was a stronger network of input and output linkages. It took someone like S1, with some affection for fishing to start something like this, but later on S2, like other farmers of his time, did it to earn higher profit.

However, even if the experiences of the two farmers were different as this study illustrates, both of them are pioneers of aquaculture in their own villages, and their actions encouraged many others in their villages to follow them into this profession. And that has translated into better economic conditions for not only themselves, but also for other people of in their villages.

\section{Conclusion:-}

The two farmers in this research are an example that farmers - or people in general - can have different experiences in their lives which leads to similar outcomes. This research does substantiate the claim from earlier quantitative studies that earning higher profit can be a motive for the converting farmer, but then adds on with the understanding of how his life experiences lead a farmer to adopt a more profitable practice. In this study, the farmer who was driven by the profit motive was in close contact with others (relatives) in the profession. Hence, he had the necessary exposure to aquaculture, plus the resources to try doing it, and thus he did it before anyone else in his village. The other farmer was not too close to aquaculture farming and was not primarily driven by the profit motive, but rather had a passion in something similar, and the attitude of trying something new. Quantitative studies about adoption of aquaculture could not observe how Mr. S2 could see the benefits of aquaculture from his uncles, let alone observing the passion for fishing by Mr. S1. This deeper understanding of the phenomenon -of change by farmers is the main takeaway from this research.

\section{Acknowledgement:-}

The author is grateful to Dr. Higinio Dominguez and the TE 931 class from spring 2016 of Michigan State University, USA for their feedback on this paper.

\section{References:-}

1. Ahmed, N. \& Toufique, K. A. (2015). Greening the blue revolution of small-scale freshwater aquaculture in Mymensingh, Bangladesh. Aquaculture Research, 46, 2305-2322. doi:10.1111/are.12390. 
2. Baxter, P. \& Jack, S. (2008). Qualitative Case Study Methodology: Study Design and Implementation for Novice Researchers. The Qualitative Report, 13 (4), 544-559.

3. BBS (2016). Statistical Yearbook of Bangladesh. Bangladesh Bureau of Statistics, Ministry of Planning, Government of the People's Republic of Bangladesh, Dhaka, Bangladesh.

4. BBS (2014). Yearbook of Agricultural Statistics- 2012. Bangladesh Bureau of Statistics, Ministry of Planning, Government of the People's Republic of Bangladesh, Dhaka.

5. Belton, B., Haque, M. M. \& Little, D. C. (2012). Does Size Matter? Reassessing the Relationship between Aquaculture and Poverty in Bangladesh. The Journal of Development Studies, 48:7, 904-922, doi: 10.1080/00220388.2011.638049.

6. Belton, B., Hein, A., Htoo, K., Kham, L. S., Nischan, U., Reardon, T. \& Boughton, D. (2015). Aquaculture in Transition: Value Chain Transformation, Fish and Food Security in Myanmar. International Development Working Paper 139, Michigan State University.

7. Belton, B., Karim, M., Thilsted, S., Murshed-E-Jahan, K., Collis, W. \& Phillips, M. (2011). Review of aquaculture and fish consumption in Bangladesh. Studies and Reviews 2011-53. The World Fish Center.

8. Dilthey, W. (1910). The construction of the historical world of the human studies. Gesammelte Schriften I-VII, Leipzig: B.G. Tuebner.

9. Doss, C.R. (2003). Understanding farm level technology adoption: lessons learned from CIMMYT's micro surveys in Eastern Africa. CIMMYT Economics Working Paper 03-07. Mexico: CIMMYT.

10. FAO (1988). Rural Aquaculture: Overview and Framework for Country Reviews. Retrieved online: http://www.fao.org/docrep/003/x6941e/x6941e04.htm

11. Flaherty, M., Vandergeest, P. \& Miller, P. (1999). Rice Paddy or Shrimp Pond: Tough Decisions in Rural Thailand. World Development, 27(12), 2045-2060.

12. Ghose, B. (2014). Fisheries and Aquaculture in Bangladesh: Challenges and Opportunities. Annals of Aquaculture and Research.

13. Gurung, K., Bhandari, H. \& Paris, T. (2016). Transformation from Rice Farming to Commercial Aquaculture in Bangladesh: Implications for Gender, Food Security, and Livelihood. Gender, Technology and Development, 20(1), 1-32. doi: 10.1177/0971852415618747.

14. Heilig, G. K. (1994). Neglected Dimensions of Global Land-Use Change: Reflections and Data. Population and Development Review, 20: 4, 831-859.

15. Hellström, I., Nolan, M. \& Lundh, U. (2005). 'We do things together' A case study of 'couplehood' in dementia. Dementia, 4 (1), 7-22. doi: 10.1177/1471301205049188

16. Hernandez, R., Belton, B., Reardon, T., Rashid, S., Ahmad, K., Zhang, X \& Ahmed, A. (2017). The Quiet Revolution in the Fish Value Chain in Bangladesh: Hidden Miracle. Aquaculture.

17. Lambin, E. F., Turner, B.L., Geist, H. J., Agbola, S. B., Angelsen, A., Bruce, J. W., ... , Xu, J. (2001). The causes of land-use and land-cover change: moving beyond the myths. Global Environmental Change, 11, 261269.

18. Nguyen, T. D. (2011). Land conversion for industrialization and its impacts on household livelihood strategies in Hung Yen province, Northern Vietnam. Rural Economics and Development. Liege, Liege University. Ph.D dissertation: 190.

19. Nguyen, T.D., Lebailly, P., Vu, D.T. \& Peemans, J. P. (2014). The Determinations of Household Agricultural Land Use Strategies in Red River Delta, Vietnam. Paper presented at Colloque SFER "Le foncier agricole : usage, tensions et régulations", Lyon, France.

20. Njue, J. N. \& Macharia, D. (2015). Factors Affecting the Development of Rainbow Trout Fish Aquaculture: Case of Mathira West District, Nyeri County Kenya. International Journal of Humanities and Social Science, 5(6:1), 161-170.

21. Rahman, M. T. (2014). A Study on Socio-Economic Conditions of Agricultural Farmers Converted To Fish Farmers of Kumarghata Union of Muktagachha Upazila in Mymensingh District. MS Thesis, Department of Aquaculture, Bangladesh Agricultural University, Mymensingh.

22. Stake, R. E. (1978). The case study method in social inquiry. Educational researcher, 7(2), 5-8.

23. Stake, R. E. (1995). The art of case study research. London: Sage Publications.

24. Thuo, A.D.M. (2013). Qualitative analysis of land use change pressures, conditions and drivers in rural-urban fringes: A case of Nairobi rural-urban fringe, Kenya. International Journal of Innovation and Applied Studies, 3(3), 820-828.

25. Yin, R. K. (1994). Case study research: Design and methods, 2nd ed., Oaks: Sage Publications. 